Pamiętnik Literacki 2021, 2, s. 79-87

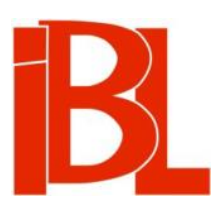

\title{
Postać emigranta: dosłownie i powieściowo
}

François Rosset 


\section{POSTAĆ EMIGRANTA: DOSŁOWNIE I POWIEŚCIOWO}

Rozwój słownictwa nakreśla czasem wyraźne różnice pomiędzy ogólnymi pojęciami dotyczącymi rzeczywistości przeżywanej przez społeczeństwa i ludzi a rozpoznawalnymi wcieleniami tej rzeczywistości. Tak jest np. w języku francuskim z rzeczownikami „émigration [emigracja]” i „émigré [emigrant]”. Pierwszy z nich był powszechnie stosowany od połowy XVIII w., by określić rozmaitego typu przemieszczenia grup ludzkich lub jednostek poza ich rodzime miejsce, podczas gdy drugi pojawia się dopiero w 1791 r., gdy zaszła potrzeba nazwania licznych uciekinierów opuszczających Francję przed groźbą rewolucji. Encyclopédie, rozprawy historyczne, eseje, jak i relacje podróżników często wspominały wcześniej o wszelkiego rodzaju emigracjach (np. wyprawy krzyżowe, prześladowania protestantów, zaludnienie Ameryki), ale nie znajdujemy tekstów, tym bardziej w dziedzinie fikcji, w których byłaby mowa o e migrantach, chociaż często w różnych dziełach występują postacie czy grupy ludzi przeżywające dobrowolnie lub przymusowo emigrację. Toteż gdy w latach 1793-1802 autorzy tacy jak Gabriel Sénac de Meilhan, Isabelle de Charrière, Stéphanie-Félicité de Genlis czy Germaine de Staël wprowadzili w świat powieści nazwanego dosłownie emigranta, wskazywali jednogłośnie na okoliczności, na mocy których pojawił się ów termin w pierwotnym, wąskim, sytuacyjnym znaczeniu. Tymczasem rozwój wydarzeń w historii kontynentu rychło narzucił rozszerzenie jego zakresu semantycznego ${ }^{1}$.

$\mathrm{W}$ tej kwestii jednak chodzi nie tylko o zagadnienie $\mathrm{z}$ historii leksyki. W przedmowie do powieści Sénaca de Meilhan L'Émigré, Wielka Rewolucja Francuska jest określona jako okropny splot wypadków, który wygenerował nowy rodzaj nieszczęśników (emigrantów właśnie), oraz jako nieznana do tej pory sytuacja, charakteryzująca się tym, iż rozróżnienie między rzeczywistością a fikcją stało się praktycznie niemożliwe: „Czy dzieło, które oddajemy publiczności, należy do gatunku powieści czy historii?”2 . Jeśli takie pytanie się nasuwa, to dlatego, że „wszystko jest jednocześnie wiarygodne i powieściowe w rewolucji Francji”, gdzie wydarzenia realne

1 Zob. B. Didi ier, Écrire la Révolution. Paris 1989. - Destins romanesques de l'émigration. Sous la dir. de C. Jaquier, F. Lotterie, C. Seth. Paris 2007. - R. Bochenek-Franczakowa, Raconter la Révolution. Louvain 2011. - Les Romans de la Révolution, 1790-1912. Sous la dir. de A. Déruelle, J.-M. Roulin. Paris 2014.

2 G. Sénac de Meilhan, L'Émigré. Éd. présentée, établie et annotée par M. Delon. Paris 2004, s. 33. Jeśli nie zaznaczono inaczej, wszystkie przekłady z języka francuskiego - F. R. 
„przekraczają wszystko, co potrafią wymyśleć powieściopisarze”3. Autor sam już nie wie, czy to, co pisze, jest powieścią. Przyznaje, że zawarł w niej to, co sam na żywo zaobserwował, ubierając jedynie ów materiał w konwencję powieści epistolarnej. Pytania, które mogłyby wyniknąc z tych autorskich stwierdzeń, nie dotyczą już samej rewolucji, lecz relacji fikcji do rzeczywistości. Sénac de Meilhan był świadkiem kolejnych epizodów rewolucji francuskiej (łącznie z pojawieniem się pierwszych emigrantów) i opisał te doświadczenia w powieści. Nie wiedział, że ścieżki jego tułaczki skieruja go w takie miejsca i okoliczności, które bezpośrednio wpłyną na szybkie rozszerzenie znaczenia nowego słowa „emigrant”.

Jak wielu innych arystokratów francuskich, Sénac de Meilhan uciekł możliwie najdalej od niebezpieczeństwa, które mu groziło. Już na jesieni 1791 (czyli w okresie, kiedy rozwój wydarzeń w Paryżu jeszcze nie wskazywał jasno na wybuch przemocy) dotarł do Warszawy, gdzie został przyjęty na dworze królewskim, jak i w najlepszych domach stolicy. Spotkał tam wtedy m.in. niemiecką pisarkę Elise von der Recke, znaną z ciętego języka, charakterystycznego dla jej pamiętników. Tak zrelacjonowała ona spotkanie $z$ literatem:

Wieczerzałyśmy u króla. Przy kolacji była obecna jedynie familia królewska, francuscy generałowie Heumann i Lambert oraz francuski pisarz Meilhan. Meilhan jest prawdziwym typem z komedii, pełnym właściwego Francuzom zadufania. Nasz dobry król przeczytał nam pochwałę rosyjskiej cesarzowej, ułożoną proza przez Meilhana. W tym utworze porównuje on Katarzynę z kościołem św. Piotra w Rzymie, który już z daleka wydaje się wielki, lecz im dokładniej bada się szczegóły tej majestatycznej budowli, tym bardziej zyskuje ona na tym. Sposób, w jaki nasz król odczytał ten utwór, prześcignął wartość tego poematu prozą ${ }^{4}$.

Trzy dni później podróżniczka notuje jeszcze:

Tego wieczora Meilhan był nieco powściągliwszy, ale jego pełne próżności zadowolenie z siebie przejawiało się w każdym słowie, w każdym geście. [...] Skromność naszego króla kontrastuje z tą zarozumiałością francuskiego pisarza ${ }^{5}$.

Salonowe plotki nabierają nieco większego znaczenia, gdy się je zestawi z portretem markiza de Saint-Alban, nakreślonym przez niemiecką hrabinę Loewenstein w czwartym liście powieści Sénaca de Meilhan:

Markiz de Saint-Alban dalej mocno cierpi. Nie opuszcza swego pokoju, a my staramy się go zabawiać, spędzając z nim dwie godziny co wieczór. Wujowi podobają się te rozmowy. Powiada, że jeszcze nie spotkał tak skromnego Francuza, a ja podzielam to zdanie, chociaż nie poznałam tak dużo Francuzów jak on, ale stwierdzam, że trudno o prostsze maniery, o sposób bardziej dyskretny i wyrozumiały, gdy [markiz] mówi o innych ${ }^{6}$.

Czy Saint-Albana, postać fikcyjną, należy traktować jako anty-Sénaca de Meilhan, prawdziwego emigranta? Zestawienie tekstów mogłoby nas do tego skłonić, ale ważniejsze jest co innego. Wiedząc bowiem, jak szczególny charakter miała zaraz po 1789 r. relacja między doświadczeniem rzeczywistości a produkcją fikcji, przyjrzyjmy się bliżej tej polskiej scence opisanej przez panią von der Recke.

Ibidem.

E. von der Re cke, Na polskim dworze królewskim. W zb.: Polska stanisławowska $w$ oczach cudzoziemców. Oprac., wstęp W. Zawa dzki. T. 2. Warszawa 1963, s. 252-253.

Ibidem, s. 253-254.

Sénac de Meilhan, op. cit., s. 43. 
Tak, jak go przedstawia niemiecka pamiętnikarka, Sénac de Meilhan jawi się jako zarozumiały pozer, który na dodatek nie jest w stanie właściwie odczytać specyfiki kontekstu, w którym się znajduje. Przyjęty na obcym dworze, zachowuje się jak na dworze à la française, ignorujac fakt, że król Stanisław August ustanowieniem Konstytucji 3 maja właśnie zakończył gruntowny proces reform państwa. Pochwała Katarzyny Wielkiej - która już zamanifestowała wówczas swoją dezaprobatę wobec owego procesu i niebawem zacznie działać, by zniweczyć polskie naruszenie starego porządku monarchistycznego - brzmiałaby jak prowokacja, gdyby nie była zwyczajnie wynikiem niewiedzy. A może Sénac de Meilhan właśnie zdawał sobie $z$ tego sprawę i dlatego zaraz opuścił Warszawę, by w Petersburgu dołączyć do dworu władczyni, którą w słowach wyjątkowo nieadekwatnych porównywał do rzymskiej Bazyliki św. Piotra?

Zachowajmy jednak ostrożność w traktowaniu przytoczonych już fragmentów. Podobnie jak deklarowane fikcje opieraja się niekiedy na najbardziej aktualnych faktach, tak i zakorzenione w obserwacji rzeczywistości dzienniki osobiste lub opinie i opisy, nakreślone przez podróżników, są uzależnione w dużej mierze od uprzedzeń i nastroju ich autorów oraz od struktur językowych i gatunkowych, nadających im formę. Stereotyp Francuza, któremu dokładnie odpowiada portret Sénaca de Meilhan, naszkicowany na żywo przez Niemkę Elise von der Recke, należy do tych figur kształtujących przedstawianie rzeczywistości, nie zaś samą rzeczywistość. Ów fragment, napisany w Warszawie pod koniec listopada 1791, nie oddaje wiernego portretu emigranta Sénaca de Meilhan, lecz prezentuje określony typ - typ francuskiego arystokraty zamkniętego w gorsecie własnych uprzedzeń, niezdolnego uchwycić różnorodności świata, w którym się znajduje. Powieści, nawet powieści francuskie, chętnie sięgają po ten stereotyp, jak np. Korynna, czyli Włochy Germaine de Staël, gdzie sylwetka hrabiego d'Erfeuil odpowiada dokładnie opisowi Sénaca de Meilhan postrzeganego przez panią von der Recke.

Ów Sénac de Meilhan nie jest już osobą, lecz postacią, która - gdyby spędziła jeszcze parę lat w Warszawie - byłaby świadkiem powstania kościuszkowskiego i niechybnie odniosłaby się do niego z takim samym brakiem zrozumienia, jaki wykazała podczas celebrowania Konstytucji 3 maja. Z pewnością też autor L'Émigré nie wzruszył się specjalnie tym, że na skutek polskich wydarzeń z lat 1794 i 1795 pojawili się na drogach Europy emigranci nowego typu, zupełnie różni od niego i jemu podobnych. Jedni musieli opuścić swą ojczyznę, gdyż przedstawiali sobą wszystko to, co miały zniweczyć odnowicielskie siły napędzone przez rewolucję. Drudzy byli ofiarami narzuconego przywrócenia w ich kraju starego porządku po ujarzmieniu dążeń reformatorskich. Poniekąd Sénac miał rację w perspektywie swych przekonań politycznych, chwaląc Katarzynę, ale mylił się, czyniąc to w Warszawie, a przede wszystkim nie zdawał sobie sprawy z tego, że głosiciele opinii zgoła odmiennych od jego własnych podzielą $z$ nim los emigranta, nadając owemu słowu nowe odniesienie w rzeczywistości i nieco szersze znaczenie. W ten sposób pewne właściwości charakteryzujące pierwszych emigrantów w historii języka francuskiego uległy odwróceniu na ziemi polskiej. Jeśli zaś chodzi o samą francuszczyznę, obserwujemy, że szybko zarejestrowała ona te zmiany. Już z początku XIX w. słowniki dodają do oczekiwanych przykładów bezpośrednio związanych $\mathrm{z}$ rewolucją („la loi sur les Émigrés”) wyrażenia zaczerpnięte z innych sytuacji (,les Émigrés 
polonais") albo stosuja to nowe słowo do określenia zjawisk niekiedy z dalekiej przeszłości („les Émigrés protestants”). Jednocześnie leksykografia francuska odnotowuje przybliżenie znaczenia wyrazów „Émigré” oraz „Réfugié [uchodźca]”, traktując je jako niemal synonimy. Specyficzny, sytuacyjny sens terminu „emigrant” definitywnie zastapiło znaczenie uogólniające. Sénac de Meilhan i Tadeusz Kościuszko czy też hugenoci $z$ epoki Ludwika XIV lub Grecy wypędzeni z Bizancjum przez Turków: wszyscy są emigrantami w tym samym, rozszerzonym znaczeniu.

Podobny proces zachodzi w dziedzinie literatury. W dziełach powstałych zaraz po 1789 r. dominuje tematyka aktualna związana $z$ rewolucją, postrzegana poprzez pryzmat osobistego doświadczenia bohaterów, wśród których pojawiają się nierzadko emigranci. Losy ich ukazują zaś rozwijający się proces dramatycznych wydarzeń, pozwalając jednocześnie obserwować, jak istniejące od dawna modele literackie służą swoimi utrwalonymi składnikami do przedstawiania nowych sytuacji. W ten sposób postacie emigrantów związanych z daną chwilą wywołują ogólniejsze reperkusje na gruncie estetyki:

1. Położenie bohaterów uciekających $z$ własnego kraju wznieca niemal automatycznie konfrontację opinii. Emigranci nie tylko skarżą się na doznawane niedole, ale też wyrażają swoje zapatrywania ideowe, które niekoniecznie łączą się w jednym rojalistycznym lamencie. Sa wśród tych postaci, oczywiście, liczni zagorzali konserwatyści, niedostrzegający innego horyzontu, jak tylko powrót do starego porządku, lecz są również sympatycy republiki, którzy żałuja jedynie, że wypadki wymknęły się spod kontroli, co doprowadziło do Wielkiego Terroru. W powieściach zawarte są także osądy w stosunku do głównych aktorów wydarzeń rewolucyjnych, czego dość spektakularny przykład stanowi Histoire du marquis de Saint-Alban zapisana w zeszycie krążacym $\mathrm{z}$ rąk do rąk wśród korespondentów powieści epistolarnej Sénaca de Meilhan - która odsyła czytelnika tego utworu do modeli klasycznej opowieści historycznej (à la César Vichard Saint-Réal lub Marie-Madelaine de La Fayette), pamiętnika (według modelu Louisa de Rouveroy de Saint-Simona) czy też rozwijającej się od końca XVII w. formy powieści-pamiętnika.

2. Emigranci często wyrażają zakłopotanie, spowodowane tym, jak postrzegają swoje relacje $z$ czasem: wydają się w nim zawieszeni, między miniona epoką, która do nich należała, a porządkiem przyszłości, którego nie potrafią określić. Ów stan rzeczy wywołuje ogólne refleksje na temat czasu historycznego, ale częściej skłania bohaterów powieści do zastanawiania się nad ich własną pozycją, podmiotów odseparowanych od uwarunkowań, od których zależało całkowicie ich społeczne bytowanie. Większość postaci odbiera tę swoją sytuację jako godną pożałowania, z rzadka jedynie traktując ja jako okazję, by poddać gruntownej weryfikacji wartości i przekonania, jakimi dotąd kierowali się w swej egzystencji wśród ludzi. Rozpoznajemy wówczas echa tradycji utopii, gdzie zostają sztucznie stworzone warunki do renegocjacji i reewaluacji takich wartości. To jakby doświadczenie wydarzeń opisanych w Wyspie niewolników Pierre’a de Marivaux, lecz tym razem w kontekście świata ukazywanego jako rzeczywisty.

3. W przestrzeń określona przez sytuację emigrantów wślizgują się też inne modele zarejestrowane w tradycji literackiej. Tak jest np. $z$ budującymi największe napięcie motywami charakterystycznymi dla tragedii klasycznej, jak choćby przymusowe rozłączenie lub bratobójcza walka. $Z$ lamentum, nostalgią i żalem, a więc 
z tonacją oczywistą dla utworów o tematyce emigracyjnej, współgrają nadane tym opowieściom formy narracyjne właściwe dla uzewnętrznienia tego, co subiektywne (opowieść w pierwszej osobie, korespondencja, dialogi).

4. Emigranta określa się jako wyobcowanego ze swego kraju, ale też jako obcego wśród nowego otoczenia, które zmusza go do pamiętania o własnej odrębności. Przypomina to sytuację protagonistów opowieści podróżniczych w wydaniu filozoficznym (jak np. w utworach Josepha-François Lafitau, Louisa Armanda de La Hontan, Cornéliusa de Pauwa, Guillaume’a-Thomasa Raynala czy Denisa Diderota), a także powieści opartych na modelu relacji podróżników. $Z$ tym że emigrant $z$ okresu rewolucji francuskiej ma to do siebie, że z racji swej pozycji, zarówno politycznej, jak i materialnej, bardzo chętnie eksponuje wszelkie jakże szlachetne składniki swej, poniżonej przez wydarzenia, tożsamości. Podobnie jak podróżujący misjonarz, naukowiec, handlarz czy filozof - emigrant patrzy na obcy świat pod wpływem własnej, jasno określonej i ograniczonej perspektywy; jednak ta specyficzna perspektywa mocno nadwyrężona przez rewolucyjne okoliczności - skłania go do trzymania się swych przekonań i uprzedzeń z tym większą zawziętością. Próba, na którą został on wystawiony, jest szczególnie trudna, a wychodzą z niej zwycięsko tylko najszlachetniejsi - powieści dostarczają ich przykładów w obfitości, m.in. markiz de Saint-Alban czy Constance w Trois femmes pani de Charrière.

Podczas gdy Sénac de Meilhan zawarł doświadczenie losów emigranta w jednej z pierwszych powieści emigracyjnych w literaturze francuskiej, inny wygnany arystokrata refleksje o ostatnich wydarzeniach historii Francji przedstawiał w świetle swego osobistego położenia. Mowa o Essai historique, politique et moral sur les révolutions anciennes et modernes considérées dans leurs rapports avec la Révolution française François-René Chateaubrianda z 1797 roku. Nie ma tu miejsca na rozpatrywanie dwuznacznego charakteru sądów o rewolucji, wyrażonych w tym dziele przez młodego pisarza $z$ punktu widzenia jego angielskiej emigracji ${ }^{7}$. Warto jednak podkreślić kilka rozwiniętych w owym eseju trafnych intuicji o osobistym doświadczeniu wygnania, a przede wszystkim o jego konsekwencjach dla dotkniętych nim jednostek, jak i - całkiem ogólnie - dla przyszłych społeczeństw.

$\mathrm{Z}$ jednej strony, znajdujemy w dziele liczne zwierzenia osobiste, np. w tonie pierwszych zdań:

Gdy opuszczałem Francję, byłem młody, a cztery lata nieszczęścia mocno mnie postarzyły. Żyjąc od czterech lat $z$ dala na wsi, bez przyjaciela, z którym mógłbym porozmawiać, bez nikogo, komu mógłbym się zwierzyć, pracując za dnia, by się utrzymać, w nocy pisząc to, co mi dyktowały smutek i refleksja, udało mi się nakreślić ten esej. Zdaję sobie sprawę z jego wad. Jeśli moje ,ja” często w nim powraca, to dlatego że zabrałem się do pisania dla siebie i tylko dla siebie. Wszędzie dostrzeżemy nieszczęśnika mówiącego do siebie samego. Jego myśli błądzą od tematu do tematu, od wspomnienia do wspomnienia. Nie kieruje nimi zamiar napisania książki, lecz jedynie potrzeba codziennego rejestrowania przygód intelektualnych, uczuć i przemyśleń. To subiektywne „ja” daje o sobie znać wszystkim autorom, którzy prześladowani przez ludzi spędzili żywot z dala od nich. Samotnicy żywią się własnym sercem, tak jak zwierzęta pozbawione pokarmu żywią się własnym ciałem ${ }^{8}$.

$7 \quad$ Zob. J.-M. Roul i n, Chateaubriand, L'exil et la gloire. Du roman familial à l'identité littéraire dans l'œuvre de Chateaubriand. Paris 1994, s. 121-155.

$8 \quad$ F.-R. de Chat e a ub ria nd, Essai historique, politique et moral [...]. W: Essai sur les révolutions. Le Génie du christianisme. Texte établi, présenté et annoté par M. Re gard. Paris 1978, s. 37. 
Los emigranta jest więc najpierw smutną i samotną próbą, doświadczoną w najgłębszych obszarach intymności przez odrzucony podmiot, który Chateaubriand nie waha się porównać do pariasa takiego, jakiego niedługo przedtem, w 1790 r., przedstawił Jacques-Henri Bernardin de Saint-Pierre w noweli La Chaumière indienne.

Ale $z$ drugiej strony, autor eseju zaznacza już w samym tytule komparatystyczny charakter zamierzonego projektu pisarskiego, gdzie rewolucja francuska, chociaż wyjątkowa, jest zestawiona $\mathrm{z}$ innymi rewolucjami, zarejestrowanymi w historii ludzkości. Nie chodzi teraz o sytuację jednostek w danym splocie wydarzeń, tylko o wymiar historii powszechnej. Zresztą Chateaubriand podkreśla też, że te najświeższe wydarzenia dotknęły z równą siłą pojedyncze osoby, jak ogół społeczeństwa, czy nawet społeczeństw w Europie:

Można mówić o sprawach przeszłości, ale kto nie patrzy bezinteresownie na aktualne wydarzenia, powinien milczeć. A gdzie można znaleźć w Europie bezstronnego obserwatora? Wszyscy od chłopa do króla zostali tak samo wplątani w tę zadziwiającą tragedię ${ }^{9}$.

Dużo później, rzucając retrospektywne spojrzenie na minione półwiecze, autor Pamiętników zza grobu wróci do tych wydarzeń, ukazując owe doświadczenia w perspektywie nie indywidualnej, lecz publicznej i nawet historycznej: „Odmieniona literaturę, którą szczyci się wiek dziewiętnasty, przyniosły emigracja i wygnanie" 10 .

Uogólniające intuicje Chateaubrianda znalazły rychło potwierdzenie w rozwoju wydarzeń, m.in. za sprawą powstania kościuszkowskiego, które - jak już wcześniej zauważyliśmy - nadało figurze emigranta nowy wymiar i nowe właściwości, natychmiast uchwycone w literaturze. Proces ten zaczyna się we Francji od tragedii Pierre'a de La Montagne L'Orphelin polonais wystawionej w 1801 r. na scenie Théâtre de la République. W ślad za owym inaugurującym dziełem namnożą się „polskie” opowiadania, powieści, dramaty i melodramaty. We wszystkich tych utworach dostrzegamy oznaki pewnej paryskiej „polonomanii” ${ }^{11}$, niemal zawsze zwiazanej $\mathrm{z}$ postacią emigranta, której istnienie $\mathrm{w}$ rzeczywistości potwierdzą powstania listopadowe i styczniowe, przyczyniając się do jej umocnienia w sferze wyobraźni.

W XIX-wiecznej Francji Polacy stali się zdecydowanie najliczniejszymi i najbardziej reprezentatywnymi wcieleniami figury emigranta $z$ jego dziwnym i jakby niedookreślonym statusem. Pojawiają się we freskach współczesnego społeczeństwa stworzonych przez Honoré de Balzaca, Gustave'a Flauberta lub Guy de Maupassanta, a także w dziełach licznych autorów, o których rzadko się dziś pamięta. Ci Polacy to

Ibidem, s. 43.

F.-R. de Chatea ubriand, Pamiętniki zza grobu. Wybór, przekł., koment. J. Guze. Warszawa 1991, s. 272.

Oto kilka przykładów ukazujących losy oraz obraz emigrantów polskich we Francji: H.-L. C o iffi e r de Verfeu, Ouliana ou l'Enfant des bois (1801); J.-L. La croix de Ni é, Ladouski et Floriska (1801); Ch.-A.-G. Pigault de l'Épin oy (Pigault-Lebrun), Métusko (1802); R.-Ch. Guilbert de Pixér é court, Les Mines de Pologne (1803); H. de La Ma is on fort, L'Héritière polonaise (1809); M.-A. B arthéle my-H a d ot, Stanislas Zamoski ou les Illustres Polonais (1811); anonimowe dzieło Les Réfugiés polonais ou tout pour l'amour et la beauté (1820) oraz M. F r o i s s e n t, Weissenfelt ou les amours de deux jeunes Polonais (1822). Zob. F. Ro s s e t, Drzewo Kraków. Mit polski $w$ literaturze francuskiej 1573-1896. Przeł. K. Bł oń s ki. Kraków 1997, s. 190-211. Zob. też J. W. B or ej s z a, Piękny wiek XIX. Warszawa 1990. 
książęta lub biedacy (jak w powieściach hrabiny Sophie de Ségur Les Deux nigauds oraz Le Général Dourakine albo też w Prostocie serca Flauberta), lekarze bądź aptekarze o dziwacznych mocach (Halpersohn w Krzywym zwierciadle historii wspótczesnej Balzaca czy Marowsko w Piotrze i Janie Maupassanta), artyści (Steinbock w Kuzynce Bietce Balzaca), zadziwiająco piękne kobiety, które przemierzały cały kontynent (hrabina Labinska w Awatarze Théophile'a Gautiera), szaleńcy (Les Aventures de Ladislas Bolski Victora Cherbulieza) - wszyscy zaś inspirowani zarówno przez liczne przykłady emigrantów mniej lub bardziej anonimowych, których Francuzi spotykali niemal codziennie w swym otoczeniu, jak i przez znane, wręcz emblematyczne osobistości: wielkich artystów (jak Adam Mickiewicz czy Fryderyk Chopin) bądź intrygujących mistyków (jak Józef Hoëné-Wroński lub Andrzej Towiański).

Te postacie odsłaniają szerszy wachlarz losów i dużo większe zróżnicowanie społeczne niż pierwotni francuscy emigranci rewolucyjni. Przyjmując ochoczo te cechy, literatura nada od razu figurze emigranta mocno wzbogacony potencjał znaczeniowy. W tej perspektywie fakt, że tak wiele wśród powieściowych emigrantów pochodzi z Polski, nie jest obojętny. Zapisują się oni w długim szeregu, zakorzenionym w ostatnich dziesięcioleciach wieku XVI, kiedy to Polska zyskała wyeksponowane miejsce we francuskim zestawieniu reprezentacji geograficznych oraz etnicznych w Europie.

Jeśli chodzi o geografię, Polska była postrzegana jako kraina odległa, często kojarzona z kresami „naszego”, tj. chrześcijańskiego, obszaru, jako niesprecyzowana przestrzeń o bezkresnym horyzoncie, której granice są w permanentnym ruchu; jako kraj zarazem ostatni $z$ „naszych” i pierwszy z „nienaszych”. Tymczasem na początku XIX w. określenie geograficzne a przynajmniej geopolityczne Polski stało się nie tylko trudne do uchwycenia, ale i zgoła bezpodstawne. Polscy emigranci są więc postaciami reprezentującymi rzeczywistość geopolityczną zdegradowaną (a może wysublimowaną?) do statusu abstrakcji. W tym sensie to idealni bohaterowie fikcyjni, których obecność w tekstach pozwala na odbiór czysto literacki czy semiotyczny, jakby niezależnie od kwestii naśladowania rzeczywistości.

We francuskim obrazie Polski w wymiarze politycznym obserwujemy także przekształcenia po okresie wielkich przemian polityczno-społecznych. Dawniej Polska oglądana z Francji była postrzegana jako dziwne państwo, na wpół monarchia, na wpół republika, gdzie sejm wybierał króla i to nierzadko wśród kandydatów obcych. Ten system momentami wydawał się obiecujący i godny naśladowania w monarchiach przeżywających kryzys (np. w dobie wojen religijnych we Francji), kiedy indziej uważany był przez władców europejskich, starających się uchodzić za oświeconych, za archaiczny i niebezpieczny (zgodnie z opinią głoszoną przez Woltera i wielu jemu współczesnych ${ }^{12}$ ). Gdy nadeszła epoka emigrantów, te zagadnienia straciły na aktualności w odniesieniu do Polski, za to okazały się w pełni relewantne w samej Francji, gdzie los polskich emigrantów stał się przedmiotem silnych starć między liberałami (deklarującymi się za wspieraniem powstańców i wygnańców) a konserwatystami (zawsze nieufnymi wobec wszelakich buntowników). Np. Balzac świetnie wykorzystuje ten motyw w Kuzynce Bietce i jeszcze bardziej w Fatszywej kochance. 
Ale i tu obserwujemy, że emigranci polscy jako postacie literackie wnoszą zagadnienia wykraczające daleko poza pole czysto politycznych debat. Jako żywe istoty pochodzace $z$ umarłego kraju sa jakby wcieleniem nadziei zmartwychwstania, postrzeganej $\mathrm{w}$ tej epoce $\mathrm{w}$ świetle silnych tendencji mistycznych, a także à propos odczytywania historii wedle takiej czy innej koncepcji postępu.

Również od strony kwestii społecznych ci wywodzący się znikąd („akcja rozgrywa się w Polsce, czyli Nigdzie") nowi emigranci inspirują nowe zagadnienia. Tu już nie chodzi - jak w przypadku francuskich emigrantów - o arystokratów, ewentualnie otoczonych resztkami wiernej służby, którzy opuścili swój kraj na czas niełaski, zanim powrócą, by zająć częściowo lub w pełni swą poprzednią pozycję w społeczeństwie. Ofiary kolejnych nieudanych powstań polskich to bowiem zarówno szlachcice i bogacze, jak chłopi i służący, oderwani od swych dawnych panów. W kraju, gdzie znaleźli schronienie, będą się starali osiągnąć na nowo swój rodzimy status społeczny, ale w zupełnie innym kontekście społeczno-politycznym, odsłaniając w ten sposób struktury i mechanizmy rządzące owym społeczeństwem.

Wreszcie odwrócenie wektora, kierunku migracji, które odnotowaliśmy, obserwując emigrantów od Sénaca de Meilhan do kościuszkowskich, otwiera w samej literaturze francuskiej możliwość odmiennego spojrzenia na relację my-inni. Teraz nie mamy już do czynienia $z$ Francuzami, którzy w tekstach francuskich skierowanych do Francuzów pozostają Francuzami w krajach obcych, gdzie losy ich rzuciły, ale $z$,innymi”, odkrywającymi we Francji rzeczywistość obcą im (znaną jednak czytelnikom tych dzieł). Owszem, będąc okazami owej nieszczęsnej, opisanej przez Chateaubrianda sytuacji wygnańców, ci „inni” cieszą się zazwyczaj sympatią przyjmującego ich społeczeństwa, ale zauważmy też, że w środowisku, w którym się znaleźli, budzą mimowolnie u tubylców uczucie zadowolenia $z$ siebie, dostarczając im okazji do kultywowania miłosierdzia, współczucia, hojności i do dokonywania cnotliwych uczynków.

Widzimy więc, jak emigrant w ubiorze polskim stał się doskonała postacią powieściową, promieniująca znacznie poza zakresem ustalonym przez specyficzną koniunkturę historyczną i polityczną Wielkiej Rewolucji Francuskiej. Jawi się jako niemal alegoryczne wcielenie niedookreślonego i jego tajemnic, wzbogaca obszar powieści o pewien egzotyzm, związany ze słabo znanym pochodzeniem i nieco innymi praktykami obyczajowymi, przedstawiając jednocześnie lub odnawiając niektóre $z$ najszlachetniejszych wartości niesionych przez literaturę co najmniej od średniowiecza: godność i bohaterstwo (któremu nieszczęście nadaje zawsze większą wartość), wierność, miłość do ojczyzny i nadzieję odkupienia.

To, co się wydarzyło od Sénaca de Meilhan do Kościuszki, to w rezultacie dużo więcej niż odwrócenie wektora. To znaczący etap głębokiej ewolucji, na którą, kończąc nasze rozważania, można spojrzeć w istotnej dla emigrantów perspektywie relacji do czasu. Bohaterowie powieści Sénaca de Meilhan żyją w zawieszeniu między przeszłością, za którą tęsknią, a niepewnym jutrem. Patrzą na czas retrospektywnie, widząc przyszłość jedynie jako przywrócenie starego porządku. Z myślą o realizacji tego celu markiz de Saint-Alban wraca potajemnie do Francji, by zaciągnąć się w szeregi armii książąt walczących $z$ republikanami. Jego śmierć nie jest zatem tylko oczekiwanym zakończeniem typowej fabuły powieściowej. Ilustruje to, co nieraz powtarzał markizowi, swemu młodemu pupilowi, naczelnik de 
Longueil: że stary świat musi ulec zmianie i że powrót do status quo ante nie jest pożądany ani nawet możliwy.

Podobnie jak bohaterowie powieści Sénaca de Meilhan, przedstawieni we francuskich fikcjach XIX-wiecznych polscy emigranci trwają w oczekiwaniu, lecz przedmiot ich nadziei, ich ojczyzna, jest jeszcze bardziej wątpliwy, skoro został de facto unicestwiony. Uosabiają samą nadzieję, samo pożądanie, brak i pragnienie, które zaspokoić moga jedynie w wymiarze symbolicznym: w sztuce i w poezji, w mistycznych wzlotach, w praktykach quasi-magicznych lub we wspomnieniach. Koniec końców przestaje być ważne, czy są oni Polakami i nawet czy są prawdziwie emigrantami. Wystarczy, że nadają ludzki kształt i metaforyczne znaczenie pojęciom emigracji i wygnania, które właśnie w tej formie leżą u podstaw owej „odmienionej literatury, którą szczyci się wiek dziewiętnasty".

\section{Abstract \\ FRANÇOIS ROSSET University of Lausanne \\ THE FIGURE OF ÉMIGRÉ: LITERAL AND NOVELISTIC MEANING}

The author of the paper analyses the evidence for the appearance of the word émigré in the French language and the changes of its scope of meaning. Initially, this word referred to a person, mostly an aristocrat, who escaped from France in the times of the French Revolution. With time, the lexeme started to be used to name a person forced to leave their home country oppressed by a military and political force, a defender of freedom that represents various social strata. The change took place mainly as a result of the Polish experience of the end of the $18^{\text {th }}$ century-the Kościuszko Uprising and partitions of Poland. The lexical perturbations were accompanied by a revision of the French people's attitude towards Poland and Poles. The French attention was captured by weirdness of country system and geopolitical situation, but also by devotion, heroism, high ethics, and love for freedom. The direction of the changes is confirmed by the French novel writings of the times. 